\title{
Neonatal mortality in Argentina. Situation analysis from 2005 to 2014
}

\author{
Juliana Z. Finkelstein, M.D. ${ }^{a}$, Mariana Duhau, M.D. ${ }^{a, b}$, María L. Fasola, M.D. ${ }^{b}$ and \\ Paola Escobar, M.D. ${ }^{b}$
}

\begin{abstract}
Introduction. Neonatal mortality (NM) refers to deaths occurring between birth and 27 days of life. This component of infant mortality has shown the least reduction over the past 50 years. The objective of this study was to analyze the course and characteristics of NM in Argentina. Population and methods. This was a descriptive, ecological study of NM in Argentina conducted between 2005 and 2014 to analyze its course, causes, and the relevance of prematurity and a low birth weight. Records of the Health Statistics and Information Department of the Ministry of Health of Argentina were used.

Results. The neonatal mortality rate reduced by $19.2 \%$ (2005: $8.9 \%$; 2014: $7.2 \%$ o); the early component (between birth and 6 days of life), by 20\% (2005: 6.5\%; 2014: 5.2\%o); and the late component (between 7 and 27 days of life), by $13 \%$ (2005: 2.3\%o; 2014: $2 \%$ ). Disorders originating in the perinatal period and congenital malformations were the cause of more than $95 \%$ of neonatal deaths in this period. The relative significance of disorders originating in the perinatal period reduced, but that of congenital malformations increased. Preterm and low birth weight live births had the greatest risk of neonatal death. A younger gestational age and a lower birth weight resulted in a lower reduction of specific neonatal mortality rate.

Conclusion. In the past 10 years, NMhas reduced significantly. Disorders originating in the perinatal period and congenital malformations were the cause of almost all deaths in this age group. NM was associated with a low birth weight and prematurity.

Key words: neonatal mortality, low birth weight infant, preterm infant, mortality causes.
\end{abstract}

http:/ / dx.doi.org/10.5546/ aap.2017.eng.343

Ministry of Health of Argentina (Ministerio de Salud de la Nación, MSAL).

E-mail address: Juliana Z. Finkelstein, M.D.:

julianazoefinkelstein@ hotmail.com

Funding:

None.

Conflict of interest:

None.

Received: $10-13-2016$

Accepted: 1-12-2017

To cite: Finkelstein JZ, Duhau M, Fasola ML, et Neonatal mortality in Argentina. Situation analysis from 2005 to 2014. Arch Argent Pediatr 2017;115(4):343349.

\section{INTRODUCTION}

Neonatal mortality includes deaths occurred in the first 27 days of life. It is the component of infant mortality that is harder to reduce, so it is also called "hard mortality."

In the past 50 years, in Argentina, infant mortality rate (IMR) has reduced by $81.4 \%$ whereas neonatal mortality rate (NMR) reduced by $71.8 \%^{1,2}$ (Figure 1). A high percentage of neonatal deaths could still be reduced. ${ }^{1,3}$

Prematurity and a low birth weight have been associated with neonatal deaths, as well as with a high burden of disease and a high prevalence of long-term complications. ${ }^{4,5}$

The development of neonatology services in Argentina as of the 1980s, together with scientific and technological advances -including the use of high-frequency ventilators and surfactants-, have contributed to the reduction of neonatal mortality. ${ }^{3}$

At present, tertiary care facilities in Argentina have the resources to diagnose and treat most health issues observed in live births. However, still some births take place in health facilities that lack the minimal resources to respond in case of delivery complications. ${ }^{6}$

The objective of this study was to analyze the course of neonatal mortality in the past 10 years and its characteristics in Argentina.

\section{POPULATION AND METHODS}

This was a descriptive, ecological study of neonatal mortality conducted in Argentina based on the vital statistics annual reports published by the Health Statistics and Information Department (Dirección de Estadísticas e Información de Salud, DEIS). The latest publication corresponded to 2014. 
Data regarding all live births and all neonatal deaths (sub-divided into two components: early and late) occurred in Argentina were analyzed.

Neonatal mortality included deaths occurring between birth and 27 days of life. Neonatal mortality rate (NMR) established a relationship between neonatal deaths occurred over a 1-year period and the number of recorded live births over that same year, and was expressed per 1000 live births. ${ }^{4}$

Neonatal mortality included early neonatal mortality (deaths occurring between birth and 6 days of life) and late neonatal mortality (those occurring between 7 and 27 days of life).

Early neonatal mortality rate (ENMR) and late neonatal mortality rate (LNMR) were estimated by establishing a relationship between deaths in each age group and live births, and were expressed per 1000 live births.

The course of NMR between 2005 and 2014, together with its components and the structure of neonatal mortality causes, was analyzed. The percentage of each disaggregated cause was analyzed for the main groups of causes. The course of birth and death percentages was analyzed by gestational age at birth (GAB) and birth weight (BW), and the specific risk of death in each group.

Full-term live births were those infants born at a gestational age (GA) of 37 weeks or more; preterm live births, those born at a GA of less than 37 weeks; and very preterm and extremely preterm
(VP\&EP) live births, those born at a GA of less than 32 weeks. $^{7}$ The risk of death in each GAB group was measured as specific NMR by relating deaths by GAB to live births with the same GAB, expressed per 1000 live births.

Adequate birth weight live births were those born with $2500 \mathrm{~g}$ or more; low birth weight (LBW) live births, those born with less than $2500 \mathrm{~g}$; and very low birth weight (VLBW) live births, those born with less than $1500 \mathrm{~g}$.

The risk of death by BW was measured as specific NMR by relating deaths by BW to live births with the same BW, expressed per 1000 live births.

Regarding ethical considerations, it should be noted that data used in this study were obtained from a secondary source (Vital Statistics - Basic information). Data processing by the DEIS protects statistical secrecy, so no consent was required for this study.

\section{RESULTS}

In 2014, 777012 live births were recorded in Argentina. Of these, 8202 infants died before turning 1 year old; 5576 deaths occurred in the neonatal period; 4019 corresponded to early neonatal deaths and the rest, to late neonatal deaths.

Over the past 10 years, IMR reduced by $20.3 \%$ whereas NMR decreased by $19.2 \%$ (2005: $8.9 \%$; 2014: 7.2\%o). ${ }^{1,2}$ ENMR reduced by $20 \%$ (2005:

FIGURE 1. Course of neonatal mortality rate and by component. Argentina. Years 1965-2014

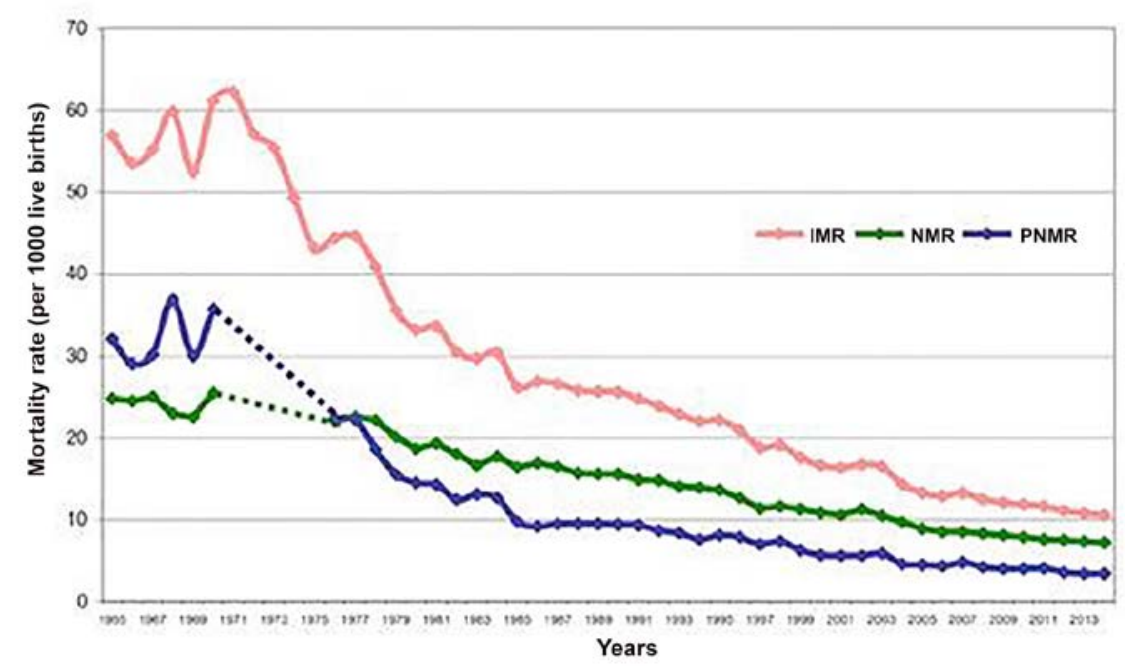

Source: DEIS. MSAL. Year 2014.

IMR: infant mortality rate; NMR: neonatal mortality rate; PNMR: post-neonatal mortality rate (per 1000 live births). 
$6.5 \% ; 2014: 5.2 \%$ ) and LNMR, by $13 \%(2005$ : $2.3 \%$; 2014: $2 \%$ ).

In 2014, the leading cause of neonatal death were disorders originating in the perinatal period $(68.3 \%)$, followed by congenital malformations, deformations and chromosomal abnormalities $(28.1 \%)$, and other causes (3.6\%).

Regarding early neonatal mortality, the leading cause of neonatal death were disorders originating in the perinatal period $(69.4 \%)$, followed by congenital malformations, deformations and chromosomal abnormalities $(28.7 \%)$, and other causes $(1.9 \%)$. In term of late neonatal mortality, the leading cause of neonatal death were disorders originating in the perinatal period $(65.4 \%)$, followed by congenital malformations, deformations and chromosomal abnormalities (26.7\%), and other causes (7.9\%).

Over the past 10 years, the relative significance of disorders originating in the perinatal period in neonatal mortality has decreased (2005: 72.9\%; 2014: $68.3 \%$ ) whereas that of congenital malformations increased (2005: 23.1\%; 2014: 28.1\%).

In 2014, disorders originating in the perinatal period were the cause of 3807 neonatal deaths $(68.3 \%)$. This group of causes was led by disorders of newborn related to length of gestation and fetal growth $(28.5 \%)$, followed by respiratory distress of newborn $(20.3 \%)$, other respiratory distress of newborn $(12.1 \%)$, and bacterial sepsis of newborn $(12 \%)$.
In the group of early neonatal mortality, the leading cause were also disorders of newborn related to length of gestation and fetal growth $(31.6 \%)$, followed by respiratory distress of newborn $(22.3 \%)$, other respiratory distress of newborn (12.8\%), and bacterial sepsis of newborn $(8 \%)$.

In the group of late neonatal mortality, the leading cause was bacterial sepsis of newborn $(22.7 \%)$, followed by disorders of newborn related to length of gestation and fetal growth $(20 \%)$, respiratory distress of newborn (15\%), and other respiratory distress of newborn $(9.9 \%)$ (Table 1 ).

In 2005, within neonatal deaths caused by disorders originating in the perinatal period, the leading cause was respiratory distress of newborn $(28.5 \%)$, followed by other respiratory distress of newborn $(12.2 \%)$, disorders of newborn related to length of gestation and fetal growth $(23.5 \%)$, and bacterial sepsis of newborn (10\%).

The second group of causes of neonatal mortality in 2014 corresponded to congenital malformations, which accounted for 1570 deaths $(28.1 \%)$. The greatest relative significance in this group corresponded to heart malformations, regardless of age range $(25.4 \%$ of neonatal deaths, $18 \%$ of early neonatal deaths, and $45.9 \%$ of late neonatal deaths) $)^{1,3,4}$ (Table 2).

In 2005, congenital malformations were the cause of 1460 neonatal deaths. Heart malformations accounted for $24.9 \%$ of neonatal

TABLE 1. Neonatal deaths and neonatal mortality components by perinatal condition. Argentina. Year 2014

\begin{tabular}{|c|c|c|c|c|c|c|}
\hline \multirow[t]{2}{*}{ Mortality causes } & \multicolumn{2}{|c|}{ Total } & \multicolumn{2}{|c|}{$\begin{array}{l}\text { Neonatal } \\
\text { Early }\end{array}$} & \multicolumn{2}{|c|}{ Late } \\
\hline & $\mathbf{N}$ & $\%$ & $\mathbf{N}$ & $\%$ & $\mathbf{N}$ & $\%$ \\
\hline Certain conditions originating in the perinatal period & 3807 & 100 & 2788 & 100 & 1019 & 100 \\
\hline $\begin{array}{l}\text { Neewborn affected by maternal factors and by complications } \\
\text { related to pregnancy, labor and delivery }\end{array}$ & 135 & 3.5 & 114 & 4.1 & 21 & 2.1 \\
\hline Disorders of newborn related to length of gestation and fetal growth & 1084 & 28.5 & 880 & 31.6 & 204 & 20.0 \\
\hline Birth trauma & 3 & 0.1 & 2 & 0.1 & 1 & 0.1 \\
\hline Intrauterine hypoxia and birth asphyxia & 176 & 4.6 & 146 & 5.2 & 30 & 2.9 \\
\hline Respiratory distress of newborn & 775 & 20.4 & 622 & 22.3 & 153 & 15.0 \\
\hline Congenital pneumonia & 46 & 1.2 & 32 & 1.1 & 14 & 1.4 \\
\hline Other respiratory distress of newborn & 459 & 12.1 & 358 & 12.8 & 101 & 9.9 \\
\hline Bacterial sepsis of newborn & 455 & 12.0 & 224 & 8.0 & 231 & 22.7 \\
\hline Omphalitis of newborn, with or without mild hemorrhage & 0 & 0.0 & 0 & 0.0 & 0 & 0.0 \\
\hline Hemorrhagic and hematological disorders of newborn & 199 & 5.2 & 114 & 4.1 & 85 & 8.3 \\
\hline Other disorders originating in the perinatal period & 475 & 12.5 & 296 & 10.6 & 179 & 17.6 \\
\hline
\end{tabular}

Source: DEIS. MSAL. Year 2014. 
deaths, $18.4 \%$ of early neonatal deaths, and $41.1 \%$ of late neonatal deaths.

In 2014, in Argentina, preterm live births accounted for $8.4 \%$ of all births, and for $64.7 \%$ of neonatal deaths, whereas VP\&EP live births corresponded to $1.2 \%$ of all live births and $46.4 \%$ of neonatal deaths. Besides, $1.3 \%$ of live birth statistical reports (LBSRs) and $13.7 \%$ of neonatal death statistical reports (DSRs) failed to record GAB. The risk of neonatal death among VP\&EP live births was 5 times higher than among preterm live births, and 164.8 times higher than among full-term live births (Table 3).

It is worth noting that these specific rates should only be interpreted as an approximation because there is a high percentage of neonatal DSRs that fail to record GAB, and this may significantly affect specific NMR by GAB.
Over the past 10 years, the number of preterm live births increased by $19.1 \%$; that of VP\&EP live births, by $26.2 \%$; and failure to record data reduced by $54.9 \%$. Neonatal deaths of preterm live births increased by $16.5 \%$; that of VP\&EP live births, by $21.9 \%$; and failure to record data reduced by $63 \%$ (Table 3 ).

Between 2005 and 2014, specific NMR among VP\&EP live births decreased by $3.8 \%$; among preterm live births, by $2.1 \%$; and among full-term live births, by $5.6 \%$ (Table 3 ).

Regarding BW, in 2014 in Argentina, preterm live births with LBW accounted for $7.1 \%$ of all births, and for $66.3 \%$ of neonatal deaths, whereas VLBW live births corresponded to $1.1 \%$ of all live births, and $48.5 \%$ of neonatal deaths. That same year, $0.9 \%$ of LBSRs and $11.4 \%$ of neonatal DSRs failed to record BW data. The risk of neonatal

TABLE 2. Neonatal deaths and neonatal mortality components by congenital malformations. Argentina. Year 2014

\begin{tabular}{|c|c|c|c|c|c|c|}
\hline \multirow[t]{2}{*}{ Mortality causes } & \multicolumn{2}{|c|}{ Total } & \multicolumn{2}{|c|}{$\begin{array}{c}\text { Neonatal } \\
\text { Early }\end{array}$} & \multicolumn{2}{|c|}{ Late } \\
\hline & $\mathbf{N}$ & $\%$ & $\mathbf{N}$ & $\%$ & $\mathbf{N}$ & $\%$ \\
\hline Congenital malformations, deformations and chromosomal abnormalities & 1570 & 100 & 1154 & 100 & 416 & 100 \\
\hline Congenital hydrocephalus and spina bifida & 55 & 3.5 & 46 & 4.0 & 9 & 2.2 \\
\hline Other congenital malformations of the nervous system & 170 & 10.8 & 156 & 13.5 & 14 & 3.4 \\
\hline Congenital malformations of heart & 399 & 25.4 & 208 & 18.0 & 191 & 45.9 \\
\hline Other congenital malformations of circulatory system & 80 & 5.1 & 36 & 3.1 & 44 & 10.6 \\
\hline Down's syndrome and other chromosomal abnormalities & 97 & 6.2 & 69 & 6.0 & 28 & 6.7 \\
\hline Other causes & 769 & 49.0 & 639 & 55.4 & 130 & 31.3 \\
\hline
\end{tabular}

Source: DEIS. MSAL. Year 2014.

TABLE 3. Comparison of neonatal mortality risk by gestational age range. Live births, neonatal deaths, and specific neonatal mortality rates by gestational age range. Argentina. Years 2005 and 2014

\begin{tabular}{|c|c|c|c|c|}
\hline & & 2005 & 2014 & Percent variation \\
\hline Total & $\begin{array}{l}\text { Live births } \\
\text { Deaths } \\
\text { NMR (per } 1000 \text { LBs) }\end{array}$ & $\begin{array}{c}712220 \\
6307 \\
8.9\end{array}$ & $\begin{array}{c}777012 \\
5576 \\
7.2\end{array}$ & $\begin{array}{c}9.1 \% \\
-11.6 \% \\
-19.1 \%\end{array}$ \\
\hline$<32$ weeks of gestational age & $\begin{array}{l}\text { Live births } \\
\text { Deaths } \\
\text { Specific NMR (per } 1000 \text { LBs) }\end{array}$ & $\begin{array}{l}7319 \\
2131 \\
291.2\end{array}$ & $\begin{array}{l}9240 \\
2589 \\
280.2\end{array}$ & $\begin{array}{l}26.2 \% \\
21.5 \% \\
-3.8 \%\end{array}$ \\
\hline$<37$ weeks of gestational age & $\begin{array}{l}\text { Live births } \\
\text { Deaths } \\
\text { Specific NMR (per } 1000 \text { LBs) }\end{array}$ & $\begin{array}{c}54635 \\
3099 \\
56.7\end{array}$ & $\begin{array}{c}65083 \\
3609 \\
55.5\end{array}$ & $\begin{array}{l}19.1 \% \\
16.5 \% \\
-2.1 \%\end{array}$ \\
\hline$\geq 37$ weeks of gestational age & $\begin{array}{l}\text { Live births } \\
\text { Deaths } \\
\text { Specific NMR (per } 1000 \text { LBs) }\end{array}$ & $\begin{array}{c}635616 \\
1146 \\
1.8\end{array}$ & $\begin{array}{c}702022 \\
1204 \\
1.7\end{array}$ & $\begin{array}{l}10.4 \% \\
5.1 \% \\
-5.6 \%\end{array}$ \\
\hline Unspecified & $\begin{array}{l}\text { Live births } \\
\text { Defunciones }\end{array}$ & $\begin{array}{c}21969 \\
2062\end{array}$ & $\begin{array}{c}9907 \\
763\end{array}$ & $\begin{array}{l}-54.9 \% \\
-63.0 \%\end{array}$ \\
\hline
\end{tabular}

NMR: neonatal mortality rate; LBs: live births.

Source: DEIS. MSAL. Year 2014. 
death among VLBW live births was 4.6 times higher than among those born with LBW, and 182.6 times higher than among those born with an adequate weight (Table 4). Once again, it is worth noting that these values should be interpreted as approximations.

Regarding the course of live births by BW in the past 10 years, the number of live births with LBW increased by $8.1 \%$; that of live births with VLBW, by $11.8 \%$; and failure to record data reduced by $20.6 \%$.

In relation to the course of neonatal deaths among live births with LBW, these reduced by 9.4\%; mortality among live births with VLBW, by $5.4 \%$; and failure to record data reduced by $14 \%$ (Table 4).

Between 2005 and 2014, specific NMR among live births with VLBW decreased by $15.2 \%$; among live births with LBW, by $16.3 \%$; and among live births with an adequate weight, by $26.1 \%$ (Table 4).

In $2014,59 \%$ of neonatal deaths could have been reduced: $28.3 \%$ by means of an adequate and timely treatment for the infant, and $26.6 \%$ by continuous care during the perinatal period; the rest $(4.1 \%)$ corresponded to other reducibility categories. ${ }^{1,3}$

It was not possible to analyze the course of neonatal mortality by reducibility criteria because the classification was reviewed in 2011 based on medical advances and technology availability. A comparison between the classification that was valid between 2005 and 2010 and the present classification was not feasible.

\section{DISCUSSION}

Over the past 10 years, IMR decreased by $20.3 \%$; NMR, by $19.2 \%$; ENMR, by $20 \%$; and LNMR, by $13 \%$. Disorders originating in the perinatal period and congenital malformations were the cause of approximately $95 \%$ of neonatal deaths. The relative significance of disorders originating in the perinatal period reduced, but that of congenital malformations increased. In terms of specific NMR by BW and GAB, a younger $\mathrm{GAB}$ and a lower $\mathrm{BW}$ resulted in a lower reduction of specific NMR.

The fact that the reduction in NMR over the past 10 years has been smaller than the reduction in IMR translated in an increase of its relative significance in infant mortality, which is consistent with worldwide trends. ${ }^{4}$

The structure of neonatal mortality causes in Argentina was similar to the causes of death in the first month of life worldwide, with disorders originating in the perinatal period as the leading cause, followed by infections (in Argentina, these accounted for a marginal percentage) and, congenital malformations in the third place. ${ }^{8}$

The trouble observed in relation to reducing the risk of death, particularly among VP\&EP and VLBW live births, appears to reflect the difficulty to modify the hard core of neonatal mortality, although it is also certainly the result of the improvements in record quality.

The percentage of preterm and LBW infants in Argentina is similar to that of developed countries; however, neonatal care outcomes differ.

TABLE 4. Comparison of neonatal mortality risk by birth weight range. Live births, neonatal deaths, and specific neonatal mortality rates by birth weight range. Argentina. Years 2005 and 2014

\begin{tabular}{llccc}
\hline & & $\mathbf{2 0 0 5}$ & $\mathbf{2 0 1 4}$ & Percent variation \\
\hline Total & Live births & 712220 & 777012 & $9.1 \%$ \\
& Deaths & 6307 & 5576 & $-11.6 \%$ \\
& NMR (per 1000 LBs) & 8.9 & 7.2 & $-19.1 \%$ \\
& Live births & 7793 & 8714 & $-5.2 \%$ \\
$<2500$ grams & Deaths & 2852 & 2705 & $-15.2 \%$ \\
& Specific NMR (per 1000 LBs) & 366 & 310.4 & $8.1 \%$ \\
$\geq 2500$ grams & Live births & 51024 & 55182 & $-9.4 \%$ \\
& Deaths & 4083 & 3698 & $-16.3 \%$ \\
& Specific NMR (per 1000 LBs) & 80 & 67 & $-1 \%$ \\
Unspecified & Live births & 661196 & 714547 & $-26.1 \%$ \\
& Deaths & 1488 & 1245 & $-20.6 \%$ \\
& Specific NMR (per 1000 LBs) & 2.3 & 1.7 & $-14.0 \%$ \\
\hline
\end{tabular}

NMR: neonatal mortality rate; LBs: live births.

Source: DEIS. MSAL. Year 2014. 
Worldwide, $11 \%$ of live births have a LBW. ${ }^{9}$ Many developing countries fail to record the birth weight of a high percentage of live births ${ }^{10}$ and, in spite of this, some countries have described a $16 \%$ of LBW infants.

In 2014, in Argentina, 7.1\% of live births had a LBW. This is similar to what has been observed in developed countries with the lowest LBW percentage ${ }^{9}$ (France: 7\%; Italy: 7\%; and the United Kingdom: 7\%). However, NMR in Argentina is higher compared to these countries ${ }^{11}$ (France: $2 \%$; Italy: 2\%o; and the United Kingdom: 2\%o). Five countries have a lower LBW percentage: Australia $(6 \%)$, Chile $(6 \%)$, Canada (6\%), Ireland $(5 \%)$, and Finland (4\%), and in all NMR is lower than in Argentina.

Worldwide, $11 \%$ of all live births are born preterm; and depending on the country, this ranges between 5\% and $18 \% .{ }^{7}$ In 2014, in Argentina, preterm live births accounted for $8.4 \%$. This is similar to the percentage in developed countries $(8.6 \%))^{12}$

Worldwide, $73 \%$ of births take place in health facilities. ${ }^{13}$

In Argentina, $99.4 \%$ of births take place in health facilities, but the conditions to solve eventual delivery complications are heterogeneous across the different facilities.

The World Health Organization established minimum requirements for maternity centers, called essential obstetric and newborn care (EONC). In 2004, in Argentina, 38\% of public maternity centers met the essential obstetric and newborn care requirements, and by $2009,44 \%$ did. $^{14}$

The Ministry of Health of Argentina, together with the UNICEF, identified that neonatology services did not comply with requirements related to infrastructure (48.2\%), equipment and instrumentation $(39.7 \%)$, and human resources: physicians $(44.1 \%)$ and nurses $(78.3 \%) .{ }^{15}$

Antenatal care should be supplemented with an improvement in risk identification; every maternity center should comply with essential obstetric and newborn care, and health care networks should be strengthened to warrant proper care. Equipment and human resource availability, especially nurses, are fundamental to assure high-quality neonatal care.

In 2008, Argentina created the National Heart Disease Program in response to the leading cause of neonatal deaths due to congenital malformations. However, in absolute and relative terms, deaths due to this cause have not reduced, and this should be further investigated in a specific study on the program's impact and outcomes. Improving pre- and post-operative care for the newborn is essential for the reduction in deaths due to this cause.

This study has some weaknesses, such as having analyzed data published by the DEIS, obtained from the Vital Statistics System and based on LBSRs and DSRs, and the fact that event under-recording (birth or death) or an incorrect identification of the cause of death in DSRs may affect analysis results. Failure to record data in LBSRs and DSRs, as described here, and data inconsistency (mainly in relation to GA and BW) are also weaknesses of the sources used in this study.

It is important to understand the relevance of proper and complete filling out of medical records, including LBSRs and DSRs, which are critical for the definition of health policies.

Finally, it is worth pointing out some of the strengths of this study, e.g., given that more than 99\% of births in Argentina take place in health facilities and that a mandatory requirement for burial implies the concurrent recording of death certificates and DSRs, there is wide coverage and recording of these events.

\section{CONCLUSION}

Over the past 10 years, in Argentina, NMR reduced by $19.2 \%$, mainly at the expense of ENMR. The causes of more than $95 \%$ of neonatal deaths were disorders originating in the perinatal period (especially respiratory disorders) and congenital malformations. Prematurity and LBW were strongly associated with neonatal mortality.

\section{REFERENCES}

1. Argentina. Ministerio de Salud de la Nación. Secretaría de Políticas, Regulación e Institutos, Dirección de Estadísticas e Información de Salud. Estadísticas Vitales. Información Básica. Año 2014. Buenos Aires: Diciembre 2015;5(58). [Accessed on:September $6^{\text {th }}$, 2016]. Available at: http: / / deis. msal.gov.ar/wp-content/uploads/2016/01/Serie5Nro58. pdf.

2. Argentina. Ministerio de Salud de la Nación. Dirección Nacional de Maternidad, infancia y Adolescencia. Salud Materno Infantil. Diagnóstico de situación República Argentina, 2005-2014. Buenos Aires, 2016. [Accessed on: September $\left.5^{\text {th }}, 2016\right]$. Available at: http: / / www.msal.gob. ar/images / stories / bes / graficos / 0000000787 cnt-lecturasdel-anuario-2014.pdf.

3. Finkelstein JZ, Duhau M, Abeyá Gilardon E, et al. Mortalidad infantil en Argentina. 3. ${ }^{a}$ revisión de los criterios de reducibilidad. Arch Argent Pediatr 2015;113(4):352-8.

4. Finkelstein JZ, Duhau M, Speranza A, et al. Evolución de la mortalidad infantil en Argentina en el marco de los Objetivos de Desarrollo del Milenio. Arch Argent Pediatr 
2016;114(3):216-22.

5. Gomella T, Cunningham M, Eyal F, et al. Retardo de crecimiento intraútero (lactante pequeño para la edad gestacional). In: Gomella TL, Eyal F, Zenk K. Neonatología. 4.ta ed. Madrid: Panamericana; 2002.Págs.524-31.

6. Argentina. Ministerio de Salud de la Nación. Dirección Nacional de Maternidad e Infancia. Análisis de la Mortalidad Materno Infantil. República Argentina, 20032012. Buenos Aires, 2014. [Accessed on: September $6^{\text {th }}$, 2016]. Available at: http://www.msal.gov.ar/images/ stories / bes/graficos / $0000000616 \mathrm{cnt}$-analisis_mortalidad_ materno_infantil_argentina-2003-2012.pdf.

7. Blencowe H, Cousens S, Oestergaard MZ, et al. National, regional, and worldwide estimates of preterm birth rates in the year 2010 with time trends since 1990 for selected countries: a systematic analysis and implications. Lancet 2012;379(9832):2162- 72.

8. GBD 2013 Mortality and Causes of Death Collaborators. Global, regional, and national age-sex specific all-cause and cause-specific mortality for 240 causes of death, 19902013: a systematic analysis for the Global Burden of Disease Study 2013. Lancet 2015;385(9963):117-71.

9. Banco Mundial. World Development Indicators: Nutrition intake and supplements. [Accessed on:September $1^{\text {st }}, 2016$ ]. Available at: http:/ / wdi.worldbank.org/table/2.19.

10. UNICEF. Tracking Progress on Chile and Maternal Nutrition. A survival and development priority 2009. New
York; 2009. [Accessed on: September $6^{\text {th }}, 2016$ ]. Available at:http:/ / www.unicef.org/publications / files/ Tracking Progress_on_Child_and_Maternal_Nutrition_EN_110309. pdf.

11. Banco Mundial. World Development Indicators: Mortality. [Accessed on: September 1 1', 2016]. Available at: http:// wdi.worldbank.org/table/2.21.

12. Howson CP, Kinney MV, Lawn JE (eds). World Health Organization. Born TooSoon: The Global Action Report on Preterm Birth. Geneva: March of Dimes - PMNCH - Save the Children - WHO; 2012. [Accessed on: September $6^{\text {th }}$, 2016]. Available at:http:/ / www.who.int/pmnch/media / news / 2012/201204_borntoosoon-report.pdf.

13. UNICEF. The State of the World's Children 2016. A fair chance for every child. Junio, 2016. [Accessed on: September 12 $\left.2^{\text {th }}, 2016\right]$. Available at: http:/ / www.unicef. org/publications / files/UNICEF_SOWC_2016.pdf.

14. Speranza A, Lomuto C, Santa María C, et al. Evaluación de maternidades públicas argentinas, 2010-2011. Rev Argent Salud Pública 2011;2(9):43-7.

15. Argentina. Ministerio de Salud de la Nación. Dirección Nacional de Maternidad e Infancia. Estudio de las Muertes de Menores de 5 años en la Argentina. Buenos Aires, 2007. [Accessed on:October $\left.3^{\text {rd }}, 2016\right]$. Available at: http: / / www. msal.gob.ar/images/stories/bes/graficos/0000000273cnts15-documento-final-emma-2007-1.pdf. 